ひきこもり家族の検討もなかったことは気にかかった，ただし評者は，本書を通読 して，この問題についてはすでに関連論文・書籍が相当に蓄積されていることを考 えれば,「ひきこもり」問題の固有性を明らかにする段階から離れ, むしろ他の諸 問題とも通ずる社会的困難へと議論を開き, 理論的射程を伸ばしていく作業が, 今 後さらに求められていることを感じた，本書はこの過渡的地点を示すものといえよ う.

土屋葉・岩永理恵・井口高志・田宮遊子 著

\title{
『被災経験の聴きとりから考える 東日本大震災後の日常生活と公的支援』
}

(生活書院，2018 年，A5 版，264 頁，2,500 円+税)

\section{金 菱 清 (東北学院大学教養学部教授)}

災害の社会調査結果において評者が判断する枢要基準は, 従来の方法論的問い直 しができているのかという点である．従来のアプローチから災害という対象を切り 取った場合，それは軽易に対象を理解することができる。しかし，災害に少しでも 携わったものならば, それは研究者の倨傲であることを甘受できるのではないか.

まるで震災の初期の頃誰しもがプロでなくてもファインダー越しにそれらしい桨害 写真を収めることができたが，時が経つに連れて即座に諒解できるような対象でな いことが覚ってくるようなものである。 それだけ東日本大震災が与えた影響が社会 科学の根幹を摇さぶる事態であった点を踏まえれば, 至極当然のこととして, 自身 が寄って立つ方法論をリフレクティブに追懐しながら対象に肉迫し新たな地平を切 り拓くことが要請される. 以上の見地から, 本書を涉猟したとき, 瞥見される社会 科学の知見とは何か.

本書の全体の構成は, 災害のなかで焦点の当たりにくい高齢者や障碍者, 生活保 護受給世帯といった「社会的弱者」に対する中長期的影響を分析することにある. 当初研究者が随意に立てた想察は, 脆弱性を抱える人たちが震災によってより大き なダメージを被るのではないか, という仮説であったが， 5 年間にわたる中長期的 な生活の変化は, 劇的なまでとはいえず, 変化もそれが災害の影響か, 災害がなく ても起きていた変化か判別が難しいと論辯する.

災害のインパクトが生活に溶け込んだものとして描いているという点では品第で きる一方で, 殊更災害の現象を扱う特段の意味は何かと鬼胎を抱かせる。つまりは, 震災以前に社会的弱者は, 丸腰ではなく, 家族やその他のネットワーク, 既存の制 度的資源などをブリコラージュしながら生活を組み立て実践躬行している，その点 からすれば，災害による剥き出しの脆弱性を補足しがたい点は仮説を立てる時点で 
既に諒解でき, 研究の嗃矢から齗跴をきたしている可能性も捨てきれない，むろん 著者たちはそれらの批判も織り达み済みで, 災害プロパーでないことを十二分に踏 まえた研究であることをあらかじめ断っている. その上で, 発生直後の配慮の關乏 と希求という段階から, 中長期的な見地からは震災の影響かどうかの峻別ができな いからこそ社会保障制度や公的支援的側面により多くを依拠するべきだという提案 は，災害という単一のパースペクティブを多角的に換骨奪胎する含意をもっていた とすれば至極もっともな明察であろう。

他方, 本書の梗概は, ある事象をインタビューとアンケートの自由記述からイン デックスを腑分けし経年変化を捉えようとしたものである. 本書の多くは, 説明 (ex-planation) として外延的に分析した中身となっている. ただし, 冒頭の批評水 準点からすれば, 震災を受けて方法論そのものを問い直す手法は各論者が寄って立 つ専門性に陰伏されていて一読しただけでは視認できない，それはいわば，解釈 （inter-pretation）として内省的に認識を深める契機になるものであるが，その端緒 が拝誦できるのは，章立ての本論稿ではなく，むしろ「コラム」においてである.

つまりは，章には格上げできないが，自分たちが調査を行う中で思量しなければな らない事柄が多く滲み出ている.

コラムの一例を採納すれば，ある全盲の夫婦は，普段の生活は目で見ることはで きないが, 認知地図が身体化されまるで世界が見えるように目視できないことを補 い, 買い物や近所への移動は難なく行ってきた。 ところが, 震災が突き付けた現実 は，それが思うように頭の中で地図を描くことができなくなるだけでなく，自ら 「迷惑をかけてはいけない」と避難所にも行けず, 集団避難の呼びかけにも応じる ことなく, 自宅に留まった結果, 原発事故によって友人のネットワークからも日常 の「(震災前の) 当たり前の」支援が届かなくなることであった．ここから透けて 見えるのは，震災前の一見牢乎に見える自前の資源やネットワークが，災害という 未知の事象に接した時に, いとも簡単に減衰ないし消散してしまうことをも伝えて くれている. 裏を返せば, 社会的弱者や被災者「自ら」が選択してしまう結果, 公 的な被災支援の対象として端から「なかった」かのように不可視化され, 支援の対 象から遺漏してしまう社会的事実を私たちに展観してくれている.

本書の地味ともいえる本タイトル『被災経験の聴きとりから考える』は, 専門性 として既存の理論的枠組み（副タイトルの「東日本大震災後の日常生活と公的支 援」) から補足できる一方で, 当事者の目線に公正に視野を合わせた時に, それに は留まらない形で, 専門性の敷居を下げた際に初めて展開される社会の豊饒性と複 雑性を私たちにあらためて伝えてくれていると愚見ながら推度した。 